\title{
AN EXPLORATION OF JOB STRESS AMONG HEALTH CARE WORK FORCE
}

\author{
Dhuha Saad Ismael', Rohat Zada², Prabhu M2* \\ 1. Center for Continuing Education, Northern Technical University, Mosul, Iraq \\ 2. Department of Business Administration, Lebanese French University, Kurdistan Region, Iraq
}

Correspondence: bordauprabhu@gmail.com

\section{ABSTRACT}

\section{OBJECTIVES:}

The aim of this study is unique and will be useful in elucidating the level and sources of job stress among nurses working in government and private sector health institutions in the Kurdistan Region. This research could be useful in developing future nursing and healthcare manpower planning policies. In this research work, the objective is to evaluate the job stress among hospital nurses in the Kurdistan region. The research part basically explains about work-related stress and how it is harmful to the health of the employees.

\section{METHODS:}

With the help of questionnaires, the authors collected primary data from the nurses working in 34 public and 56 private hospitals all over the Kurdistan region. To collect the data author used a simple random sampling method. The proposed study is descriptive in nature and authors collected data from 252 staff nurses working in the Kurdistan region. To do the analysis author used statistical tools like descriptive statistics, mean, cluster, chi-square, and correspondence analysis. To analyses, the data author used statistical software package SPSS 28.

\section{RESULTS:}

The results reveals that the ranking of four job stress domains like job factor, organizational factors, interpersonal relations factors and environmental factors. In that the interpersonal relations factors are ranked number one and the second rank is organizational factors third one is environmental factors and the last one is job factor.

\section{CONCLUSIONS:}

In Kurdistan region hospital staff nurses stressed due to routine shift and poor organizational structure are mostly influenced on organizational factors that are why it's ranked number one among the four domains.

\section{KEYWORDS}

Job stress, health, hospital, nurses, chi-square 
Nursing has been distinguished as a noble occupation and also it has given inherent amounts of pressure to the nurses. Occupation stress achieved dangerous effects on attendants' well-being and their capacities to adapt to work requests. Nowadays, work-related stress is recognized as a severe worldwide issue for employees and every organization. Many researchers revealed that work-related stress could cause many thoughtful health issues and adversely affect organizational results. People who suffer from work-related stress are more likely to have stumpy motivation, unhealthy lifestyle, less production, poor satisfaction levels, and feel not secure at the workplace. Those work-related stresses not only affect the work environment but also affect the employees' work-life balance and create pressure on work and their family life. Occupational stress produces negative outcomes for employees, including high healthcare fees. [1,2] The aim of this study is unique and will be useful in elucidating the level and sources of job stress among nurses working in government and private sector health institutions in the Kurdistan Region. This research could be useful in developing future nursing and healthcare manpower planning policies. The study's findings will contribute to the body of theoretical knowledge on human resource management and coping strategies for nurses in the healthcare industry.

\section{LITERATURE REVIEW}

At the most critical measurement, the pressure is our frame's reaction to weights from a condition or lifestyle occasion. What adds to stress can shift exceptionally from character to person and contrasts as indicated through our social and monetary situations, the earth we live in and our hereditary cosmetics. Some regular highlights of factors that could make us experience stress comprise encountering something new or startling, something that undermines our sentiment of self or feeling we've got little strength over a scenario. [3]

Stress can be characterized as how we feel overpowered or unfit to adapt because of unmanageable pressure. [4,5] Numerous factors can be the reason behind stress, such as the death of a loved one, separation or divorce, redundancy, and financial difficulties. [6] However, some positive changes can also lead to stress, such as moving to a bigger city, receiving a job promotion, or a short

weekend trip. [7,8] Stress has been categorized as a person or something present or going on earlier than, specifically as the motive or origin of something current or taking place later or stimulus, as a result, or response and as an interaction. It has been studied from diverse frameworks. For example, a physiological evaluation changed into proposed helps thinking about the association between pressure and illness. $[9,10]$

On the other hand, Lazarus and Folkman [11] argued for a psychological perception in which stress is "a specific relationship between an individual and the environment that the individual appraises as taxing or exceeding his or her resources and endangering his or her health." Job stress is identified with one's activity. It often originates from unexpected duties and pressure that do not align with an individual's knowledge, aptitudes, or desires, hindering one's ability to adapt. Job stress can increment when employees do not feel upheld by administrators or partners or feel they have little command over work processes. [12] Stress can result from complex interactions between large frames of interrelated factors; there are several psychological theories and models that address job stress. $[13,14]$ In addition, work stress is identified as a problem in health care workers, and nursing has been recognized as an occupation with significant stress levels. Previous studies have established that stress leads to dangerous effects on nurses' health and ability to meet job demands. [15] This significantly impairs the availability of delicate care and the efficacy of fitness services shipping. [16] Stress exists in every employer both huge and small the work locations and companies have ended up loads complex due to which it exists, job-related stress has tremendous effects over the personnel job normal overall performance, and the corporations are seeking to deal with this scenario. $[17,18]$

In truth, work-associated stress has been labelled as significant health trouble. Interestingly, Work pressure in nursing became first examined and recognized for hysteria among nurses categorized: Patient care, decision making, taking duty, and change. The nurse's role has long been seen as stress-stuffed primarily based on physical labor, human suffering, work hours, staffing, and interpersonal relationships that are important to the work nurses do. Since the mid-Nineteen Eighties, nurses' paintings strain has been escalating due to the increasing use of generation, continuing rises in fitness care prices, and turbulence inside the paintings' surroundings. [19] 
People in human beings and employees, in particular, can deal with strain for brief intervals; however chronic pressure produces prolonged changes in the physiological nation. The issues of task stress, coping, and burnout amongst nurses are of the usual challenge to all managers and administrators in fitness care. Following this view, work stress exists while human beings understand that they have trouble coping with the needs regarding work and that their feelings of nicely-being are being threatened. Many stressors associated with nursing have been identified. All these stresses may be changed pleasingly via the usage of suitable stress control abilities. [20-22] A few stressors are typically encountered by using nurses. [23,24]

Thus, this examination geared toward finding out the diploma of expert stress many of the body of workers nurses and various determinants, which affect it so that strategies to improve their private and expert first-rate of existence may be deliberate out ultimately. The study's main objective is to evaluate the job stress among hospital nurses in the Kurdistan region.

\section{RESEARCH METHODOLOGY}

The proposed study is descriptive, and the authors collected data from 252 staff nurses who work in 56 private and 34 public hospitals located in the Kurdistan region. In this research work, the authors used both primary and secondary data. To collect the primary data, the authors used well-strucutred questionnaires and duration for collecting of the data is from May 2021 to July 2021. It contains two sections the first section covers eight demographical variables like name, the gender of the respondents, marital status, age of the respondent, nationality, monthly salary, educational level and length of service in the present position. The second section covers 29 job stress-related variables. It is further subdivided into four domains, namely job factors, organizational factors, interpersonal relations factors, and environmental factors. All are on a five-point Likert scale. Information is collected from nurses those who work in both day and night shift. To collect the data author used a simple random sampling method. The author used statistical tools like descriptive statistics, mean, cluster, chi-square, and correspondence analysis to do the analysis. For data analyses author used SPSS.28 statistical software package. Before starting the analysis authors checked the reliability of the data. Cronbach's Alpha analysis is used to test the internal consistency of the scale. They conducted a reliability test for all job stress-related variables. The minimum recommended value for the Cronbachs alpha coefficient is 0.06.[25]

\section{TABLE 1 RELIABILITY TEST}

\begin{tabular}{|l|l|l|}
\hline SIno & Particulars & Cronbach's Alpha \\
\hline 1 & Job factor & 0.890 \\
\hline 2 & Organizational factors & 0.943 \\
\hline 3 & Interpersonal relations factors & 0.927 \\
\hline 4 & Environment factors & 0.912 \\
\hline
\end{tabular}

In our study, table 1 portrays the Cronbachs alpha value as more than the recommended value for four domains Job factor, Organizational factors, Interpersonal relations factors, and Environment factors are ranging from 0.890 to 0.943, respectively. Table 1 shows that all constraints have passed the reliability test where all alpha - values have exceeded the recommended minimum value of Cronbach's alpha. This indicates that the variables of various domains have good internal consistency.

\section{ANALYSIS AND RESULTS}

Table 2 provides the following details concerning the demographic characteristics of respondents items like the gender of the respondents, marital status, accommodation, age of the respondent (years), monthly salary (US\$), length of service in the present position and distance from home to workplace. 


\section{BASIC CAUSES OF JOB STRESS AMONG THE KURDISTAN HOSPITAL NURSES}

From the above table, three portraits show the ranking of job stress domains of Kurdistan hospital nurses. In these four stress factors, interpersonal relations factor ranked number one, organizational factor ranked second, environment factors ranked third and the last one is job factor.

Many researchers are argued about hospital staff nurses regarding job stress and the causes of stress. In this research, the author ranked the stress factors based on opinions collected from the Kurdistan staff nurses. Table 3 shows the ranking of job stress variables in that job factors domain role conflict, job autonomy, and role contradiction has the highest-ranking rate. It shows the staff nurses in Kurdistan face more stress due to role conflict, job autonomy, and role contradiction. The variables like word load and role ambiguities have a moderate level in the job factor domain. The variable like responsibility and job identity have the lowest score. It shows that the responsibility and job identity variables have fewer stress causes among the Kurdistan staff nurses.

Organizational factor domains show that shift work is ranked number one, and it shows that the staff nurses are highly stressed based on shift work. Moreover, the organizational structure variable scored the minor rank. It shows that staff nurses are happy about the structure of the organization. In the domains of interpersonal relations factors, management style ranked number one, and the variable organizational support variable ranked sixth, indicating that nurses in the Kurdistan region get good support for the organization. It can be inferred from the environment domain staff nurses are worried about the hygienic condition in the hospital and happy about the working conditions it scored the least score in the environment factor domain. With the attempt of conducting an inept study on the job stress domain of Kurdistan staff nurses, cluster analysis has been used; it helps to segregate the respondents into a different group.

TABLE 2 DEMOGRAPHIC CHARACTERISTIC OF THE SAMPLING FREQUENCY AND THE PERCENTAGE OF THE RESPONDENTS $(\mathrm{N}=252)$

\begin{tabular}{|c|c|c|}
\hline Characteristic & Frequency & Percentage \\
\hline \multicolumn{3}{|l|}{ Gender } \\
\hline Male & 92 & 36.50 \\
\hline Female & 160 & 63.50 \\
\hline \multicolumn{3}{|l|}{ Marital status } \\
\hline Married & 91 & 36.10 \\
\hline Unmarried & 161 & 63.90 \\
\hline \multicolumn{3}{|l|}{ Accommodation } \\
\hline Bachelor & 21 & 8.30 \\
\hline Forced bachelor & 64 & 25.40 \\
\hline With family & 167 & 66.30 \\
\hline \multicolumn{3}{|c|}{ Age of the Respondent (years) } \\
\hline Below 20 & 37 & 14.70 \\
\hline 21 to 30 & 184 & 73.00 \\
\hline 31 to 40 & 23 & 9.10 \\
\hline 41-above & 8 & 3.20 \\
\hline \multicolumn{3}{|l|}{ Monthly salary } \\
\hline Up to 400 US\$ & 35 & 13.90 \\
\hline 401 to 600 US\$ & 155 & 61.50 \\
\hline 601 and above US\$ & 62 & 24.60 \\
\hline \multicolumn{3}{|c|}{ Length of service in the present position } \\
\hline Below 2 year & 68 & 27.00 \\
\hline $2-5 y e a r$ & 154 & 61.10 \\
\hline 6-10 year & 24 & 9.50 \\
\hline Above 10 year & 6 & 2.40 \\
\hline
\end{tabular}




\begin{tabular}{|l|l|l|}
\hline Distance from home to the workplace \\
\hline Around $1 \mathrm{~km}$ & 43 & 17.10 \\
\hline $1-5 \mathrm{~km}$ & 101 & 40.10 \\
\hline $5-10 \mathrm{~km}$ & 90 & 35.70 \\
\hline Above $10 \mathrm{~km}$ & 18 & 7.10 \\
\hline
\end{tabular}

TABLE 3 RANKING OF JOB STRESS VARIABLES

\begin{tabular}{|c|c|c|c|}
\hline SIno & Particulars & Mean & Rank \\
\hline I & Job factor & 2.96 & 4 \\
\hline 1 & Job identity & 2.70 & 7 \\
\hline 2 & Workload & 2.97 & 4 \\
\hline 3 & Responsibility & 2.88 & 6 \\
\hline 4 & Role ambiguity & 2.95 & 5 \\
\hline 5 & Role contradiction & 3.05 & 3 \\
\hline 6 & Role Conflict & 3.11 & 1 \\
\hline 7 & Job Autonomy & 3.07 & 2 \\
\hline II & Organizational factors & 3.11 & 2 \\
\hline 1 & Organizational structure & 2.92 & 10 \\
\hline 2 & Policies and procedures & 3.03 & 8 \\
\hline 3 & Pay & 3.01 & 9 \\
\hline 4 & Rewards & 3.13 & 5 \\
\hline 5 & Recognition and promotion & 3.12 & 7 \\
\hline 6 & Job security & 3.13 & 6 \\
\hline 7 & Leadership style & 3.20 & 2 \\
\hline 8 & Training programs & 3.15 & 4 \\
\hline 9 & Shift work & 3.23 & 1 \\
\hline 10 & Career Advancement & 3.15 & 3 \\
\hline III & Interpersonal relations factors & 3.11 & 1 \\
\hline 1 & Organizational Support & 2.98 & 6 \\
\hline 2 & Co-worker support & 3.13 & 4 \\
\hline 3 & Patient behaviors & 3.00 & 5 \\
\hline 4 & Communication quality & 3.16 & 3 \\
\hline 5 & Working Relationships & 3.17 & 2 \\
\hline 6 & Management Style & 3.21 & 1 \\
\hline IV & Environment factors & 3.08 & 3 \\
\hline 1 & Working conditions & 2.99 & 6 \\
\hline 2 & Health/cold, noise & 3.01 & 5 \\
\hline 3 & Space for work & 3.10 & 3 \\
\hline 4 & Facilities & 3.15 & 2 \\
\hline 5 & Physical Environment & 3.07 & 4 \\
\hline 6 & Hygienic condition & 3.17 & 1 \\
\hline
\end{tabular}

\section{SEGMENTATION OF RESPONDENTS BASED ON JOB STRESS}

Cluster analysis has been used to segment the respondents based on job stress domains. K-mean cluster analysis has been used to segment the homogeneous group of the respondent based on the job stress domain. This analysis helped to handle a large number of the respondent and segregated into a related group. 
By applying the K-mean cluster analysis, the respondents are segmented into three groups namely "Highly job stressed group", "Moderately job stressed group," and "Low job stressed group". Based on the mean value of the four domains, the first cluster scored 2.8975 and it's named as moderately job stressed group. The second cluster average score is 3.5475 and it is ranked number one and high when compared to another group, so it is named as highly job stressed group and the third cluster scored is 2.025 it very less compare to the other two groups so it is named as Low job stressed group.

It can be concluded from the above table that the $F$ values of the four domains are statistically significant, and the values are less the 0.05 . This implies that the three clusters are different significantly.

Table 6 displays the numbers of respondents are in the cluster each cluster. It can be observed from the above table that each cluster contains an almost equal number of respondents. Hence, the three clusters have almost equal strength and there is not much variance.

\section{ASSOCIATION BETWEEN JOB STRESS AND DEMOGRAPHIC VARIABLE}

It is necessary to understand the association between job stress segment and demographic variable impact. For that, the chi-square test is applied in this research. The following tables portray the chi-square value and their significance for the association between the job stress segment and the demographic variable. The demographic variable included is Gender, Marital status, Accommodation, Age of the Respondent (years), Monthly salary, Length of service in the present position, and Distance from home to the workplace.

TABLE 4 THE SEGMENT OF JOB STRESS IN FINAL CLUSTER CENTERS

\begin{tabular}{|l|l|l|l|}
\hline \multirow{2}{*}{ Domains } & \multicolumn{3}{l|}{ Cluster } \\
\cline { 2 - 4 } & 1 & 2 & 3 \\
\hline \hline Job factor & 2.83 & 3.36 & 2.09 \\
\hline Organizational factors & 3.00 & 3.59 & 1.96 \\
\hline Interpersonal relations factors & 2.90 & 3.65 & 1.97 \\
\hline Environment factors & 2.86 & 3.59 & 2.08 \\
\hline Average & 2.8975 (II) & 3.5475 (I) & 2.025 (III) \\
\hline
\end{tabular}

TABLE 5 ANOVA

\begin{tabular}{|l|l|l|}
\hline Domains & F & Sig. \\
\hline Job factor & 149.084 & .000 \\
\hline Organizational factors & 401.666 & .000 \\
\hline Interpersonal relations factors & 396.085 & .000 \\
\hline Environment factors & 300.819 & .000 \\
\hline
\end{tabular}

TABLE 6 ARRANGEMENT OF THE CLUSTERS

\begin{tabular}{|l|l|l|l|}
\hline Cluster & Cluster name & $\begin{array}{l}\text { Number } \\
\text { Cases }\end{array}$ & of \\
\hline 1 & Modercentage \\
\hline 2 & Highly job stressed group job stressed group & 82 & $32.54 \%$ \\
\hline 3 & Low job stressed group & 126 & $50 \%$ \\
\hline Valid & & 44 & $17.46 \%$ \\
\hline
\end{tabular}


TABLE 7 CHI-SQUARE VALUE FOR DEMOGRAPHIC VARIABLES

\begin{tabular}{|l|l|l|l|l|l|}
\hline $\begin{array}{l}\text { SL. } \\
\text { No }\end{array}$ & Variables & Value & df & Sig. & Significant or not \\
\hline 1 & Gender & 19.991 & 2 & .000 & Significant \\
\hline 2 & Marital status & 1.045 & 2 & .593 & Not Significant \\
\hline 3 & Accommodation & 7.872 & 4 & .096 & Not Significant \\
\hline 4 & Age of the Respondent (years) & 58.759 & 6 & .000 & Significant \\
\hline 5 & Monthly salary & 9.987 & 4 & .041 & Significant \\
\hline 6 & Length of service in the present position & 21.465 & 6 & .002 & Significant \\
\hline 7 & Distance from home to workplace & 31.161 & 6 & .000 & Significant \\
\hline
\end{tabular}

It can be inferred from the above table that there is an association between the job stress segment and demographic variables. The demographic variable like Gender, Age of the Respondent (years), Monthly salary, Length of service in the present position and Distance from home to workplace variables has proved an association among job stress segment and demographic variable. It is found that there is no association between job stress segment and demographic variables like marital status and accommodation.

\section{GENDER OF THE RESPONDENT AND JOB STRESS SEGMENT}

To find out the association between the gender of the respondent and the job stress segment, the authors applied chi-square analysis. The job stress factors are in the form of metrics; the researcher converted the metric data into category data by applying cluster analysis. The crosstabulation between the gender of the respondent and the job stress segment is shown in the following table.

\section{TABLE 8 GENDER OF THE RESPONDENT AND JOB STRESS SEGMENT}

\begin{tabular}{|ll|l|l|l|}
\hline \multirow{2}{*}{$\begin{array}{l}\text { Gender of the Job stressed group } \\
\text { respondents }\end{array}$} & $\begin{array}{l}\text { Moderately job } \\
\text { stressed group }\end{array}$ & $\begin{array}{l}\text { Highly job } \\
\text { stressed group }\end{array}$ & $\begin{array}{l}\text { Low job stressed } \\
\text { group }\end{array}$ & \multirow{2}{*}{ Total } \\
\hline Male & $48.9 \%$ & $42.4 \%$ & $8.7 \%$ & $100.0 \%$ \\
\hline Female & $23.1 \%$ & $54.4 \%$ & $22.5 \%$ & $100.0 \%$ \\
\hline Total & $32.5 \%$ & $50.0 \%$ & $17.5 \%$ & $100.0 \%$ \\
\hline
\end{tabular}

TABLE 9 AGE OF THE RESPONDENT (YEARS) AND JOB STRESS SEGMENT

\begin{tabular}{|l|l|l|l|l|}
\hline \multirow{2}{*}{$\begin{array}{l}\text { Age of the } \\
\text { Respondent } \\
\text { (years) }\end{array}$} & $\begin{array}{l}\text { Job stressed group } \\
\text { stressed group }\end{array}$ & $\begin{array}{l}\text { Moderately job } \\
\text { stressed group }\end{array}$ & $\begin{array}{l}\text { Low } \\
\text { stressed group }\end{array}$ & \\
\hline Below 20 & $21.6 \%$ & $78.4 \%$ & $.0 \%$ & $100.0 \%$ \\
\hline 21 to 30 & $37.5 \%$ & $47.3 \%$ & $15.2 \%$ & $100.0 \%$ \\
\hline 31 to 40 & $21.7 \%$ & $43.5 \%$ & $34.8 \%$ & $100.0 \%$ \\
\hline 41 and above & $.0 \%$ & $.0 \%$ & $100.0 \%$ & $100.0 \%$ \\
\hline Total & $32.5 \%$ & $50.0 \%$ & $17.5 \%$ & $100.0 \%$ \\
\hline
\end{tabular}




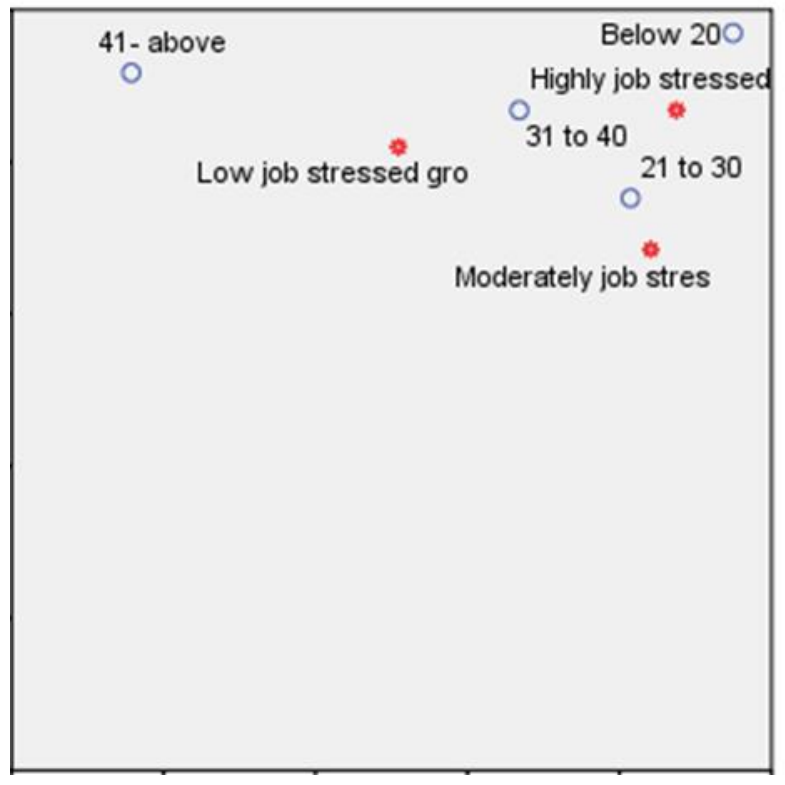

It can be inferred from the above cross-tabulation table that the gender of the respondent's category of male (48.90\%) comes under moderately job stressed group. The gender of the respondent category of females comes under the highly job stressed group. It shows that females feel more stressed than males.

\section{AGE OF THE RESPONDENT (YEARS) AND JOB STRESS SEGMENT}

The author wants to find out the association between the age of the respondent (years) and the job stress segment, and the authors applied chi-square analysis. The job stress factors are in the form of metrics. The researcher converted the metric data into category data by applying cluster analysis. The cross-tabulation between the age of the respondent (years) and the job stress segment are shown in the following table.

From the above cross-tabulation table, it can be inferred that the age of the respondent category of below 20, 21 30, and 31-40 comes under the highly job-stressed group. The age of the respondent category of 41 and above comes under the low job stressed group. It shows that youngers are more stressed than old staff.

The above figure displays the result of the correspondence analysis explaining the association between the age of the respondent and the job stress segment. The figure explicates that those under the category of below 20 and 31 to 40 are closely associated with a highly job stressed group. Those who come under the category of 21 to 30 are closely associated with moderately job-stressed groups. The age category of 41 and above come under the low job stressed group.

\section{MONTHLY SALARY AND JOB STRESS SEGMENT}

The main motto of the research is to find out the association between the monthly salary of the respondent and the job stress segment, so the authors applied chi-square analysis. The job stress factors are in the form of metrics, the researcher converted the metric data into category data by applying the cluster analysis. The cross-tabulation between the monthly salary of the respondent and the job stress segment is shown in the following table.

It can be observed from the cross-tabulation table that the monthly salary of the respondent's category of up to 400US\$ and 401 to 600 US\$ comes under a highly job stressed group. The monthly salary of the respondent category of those who get a salary of 601 and above US\$ comes under low job stressed group. It shows that those who get more salary feels less stressed than others. 
TABLE 10 MONTHLY SALARY AND JOB STRESS SEGMENT

\begin{tabular}{|l|l|l|l|l|}
\hline Monthly salary & \multicolumn{2}{l|}{ Job stressed group } & Total \\
\cline { 2 - 4 } & $\begin{array}{l}\text { Moderately job } \\
\text { stressed group }\end{array}$ & $\begin{array}{l}\text { Highly job stressed } \\
\text { group }\end{array}$ & $\begin{array}{l}\text { Low job stressed } \\
\text { group }\end{array}$ & \\
\hline Up to 400 US\$ & $28.6 \%$ & $62.9 \%$ & $8.6 \%$ & $100.0 \%$ \\
\hline 401 to 600 US\$ & $33.5 \%$ & $51.6 \%$ & $14.8 \%$ & $100.0 \%$ \\
\hline 601 and above US\$ & $32.3 \%$ & $38.7 \%$ & $29.0 \%$ & $100.0 \%$ \\
\hline Total & $32.5 \%$ & $50.0 \%$ & $17.5 \%$ & $100.0 \%$ \\
\hline
\end{tabular}

FIGURE 2 MONTHLY SALARY AND JOB STRESS SEGMENT

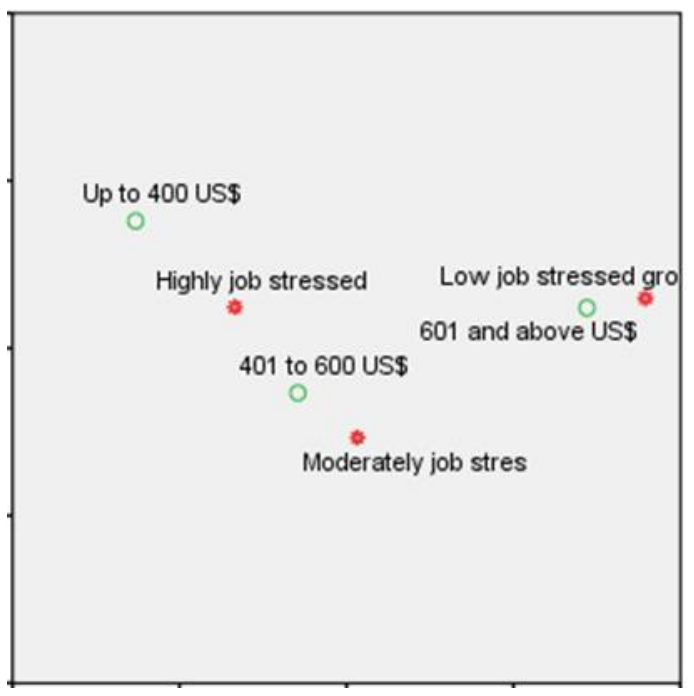

Job stressed group

Monthly salary

The above figure shows the result of the correspondence analysis enlightening the association between the monthly salary of the respondent and the job stress segment. The figure explicates that those under the category of up to 400uS\$ are closely associated with a highly job stressed group. Those who come under the category of 401 to 600 US\$ are closely associated with moderate job stressed groups and 601 and above US\$ comes under low job stressed group.

\section{LENGTH OF SERVICE IN THE PRESENT POSITION AND JOB STRESS SEGMENT}

In this research, the author wants to find out the association between the length of service in the respondent's present position and the job stress segment, for those authors applied chi-square analysis. The job stress factors are in the form of metric, and the researcher converted the metric data into category data by applying cluster analysis. The cross-tabulation between the length of service in the present position of the respondent and the job stress segment is shown in the following table.

\section{TABLE 11 LENGTH OF SERVICE IN THE PRESENT POSITION AND JOB STRESS SEGMENT}

\begin{tabular}{|l|l|l|l|l|}
\hline $\begin{array}{l}\text { Length of service } \\
\text { in the present }\end{array}$ & Job stressed group & \multicolumn{2}{|l|}{ Total } \\
position & $\begin{array}{l}\text { Moderately job } \\
\text { stressed group }\end{array}$ & $\begin{array}{l}\text { Highly job stressed } \\
\text { group }\end{array}$ & $\begin{array}{l}\text { Low job stressed } \\
\text { group }\end{array}$ & \\
\hline Below 2 year & $25.0 \%$ & $55.9 \%$ & $19.1 \%$ & $100.0 \%$ \\
\hline $2-5$ year & $39.6 \%$ & $45.5 \%$ & $14.9 \%$ & $100.0 \%$ \\
\hline $6-10$ year & $.0 \%$ & $66.7 \%$ & $33.3 \%$ & $100.0 \%$ \\
\hline Above 10 year & $66.7 \%$ & $33.3 \%$ & $.0 \%$ & $100.0 \%$ \\
\hline Total & $32.5 \%$ & $50.0 \%$ & $17.5 \%$ & $100.0 \%$ \\
\hline
\end{tabular}


TABLE 11 LENGTH OF SERVICE IN THE PRESENT POSITION AND JOB STRESS SEGMENT

\begin{tabular}{|l|l|l|l|l|l|}
\hline \multirow{2}{*}{$\begin{array}{l}\text { Length of service } \\
\text { in the present } \\
\text { position }\end{array}$} & $\begin{array}{l}\text { Moderately job } \\
\text { stressed group }\end{array}$ & $\begin{array}{l}\text { Highly job stressed } \\
\text { group }\end{array}$ & $\begin{array}{l}\text { Low job stressed } \\
\text { group }\end{array}$ & \multicolumn{1}{|l|}{ Total } \\
\hline Below 2 year & $25.0 \%$ & $55.9 \%$ & $19.1 \%$ & $100.0 \%$ \\
\hline $2-5$ year & $39.6 \%$ & $45.5 \%$ & $14.9 \%$ & $100.0 \%$ \\
\hline $6-10$ year & $.0 \%$ & $66.7 \%$ & $33.3 \%$ & $100.0 \%$ \\
\hline Above 10 year & $66.7 \%$ & $33.3 \%$ & $.0 \%$ & $100.0 \%$ \\
\hline Total & $32.5 \%$ & $50.0 \%$ & $17.5 \%$ & $100.0 \%$ \\
\hline
\end{tabular}

FIGURE 3 LENGTH OF SERVICE IN THE PRESENT POSITION AND JOB STRESS SEGMENT

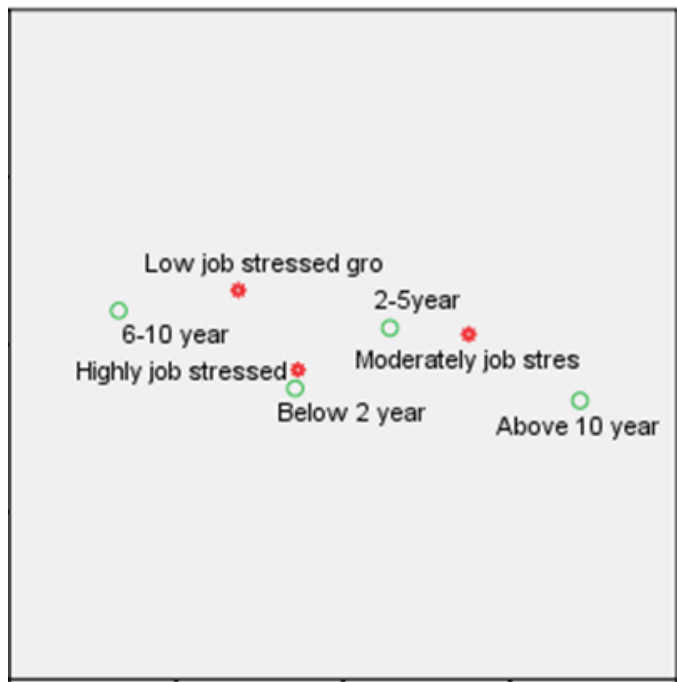

* Job stressed group

Length of service in the present

position

The above table portraits the category of those staff working in Kurdistan hospital below two years, 2-5 years, 610 years length of service in the present position come under a high job stressed group. The category of staff under the above 10 years' service in the present position comes under a moderately stressed group. It shows that experienced staffs feel less stressed than others.

The above figure displays the result of the correspondence analysis clarifying the association between the length of service in the present position and the job stress segment. The figure explicates that those under the category of up to below 2 years are closely associated with a highly jobstressed group. Those who come under the category of 2 5 years and above 10 years are closely associated with moderately job stressed groups, and 6-10 years come under low job stressed groups.

\section{DISTANCE FROM HOME TO WORKPLACE AND JOB STRESS SEGMENT}

The authors investigated the association between the distance from home to the workplace of the respondent and job stress segment, for that authors applied chi-square analysis. The job stress factors are in the form of metrics, the researcher converted the metric data into category data by applying the cluster analysis. The cross-tabulation between distance from home to the workplace of the respondent and job stress segment is shown in the following table. 
TABLE 12 DISTANCE FROM HOME TO THE WORKPLACE AND JOB STRESS SEGMENT

\begin{tabular}{|c|c|c|c|c|}
\hline \multicolumn{4}{|c|}{ Distance from home to the Job stressed group } & \multirow{2}{*}{ Total } \\
\hline workplace & $\begin{array}{l}\text { Moderately job } \\
\text { stressed group }\end{array}$ & $\begin{array}{l}\text { Highly job } \\
\text { stressed group }\end{array}$ & $\mid \begin{array}{ll}\text { Low } & \text { job } \\
\text { stressed group }\end{array}$ & \\
\hline Around 1km & $41.9 \%$ & $23.3 \%$ & $34.9 \%$ & $100.0 \%$ \\
\hline $1-5 \mathrm{~km}$ & $28.7 \%$ & $50.5 \%$ & $20.8 \%$ & $100.0 \%$ \\
\hline $5-10 \mathrm{~km}$ & $30.0 \%$ & $65.6 \%$ & $4.4 \%$ & $100.0 \%$ \\
\hline Above $10 \mathrm{~km}$ & $44.4 \%$ & $33.3 \%$ & $22.2 \%$ & $100.0 \%$ \\
\hline Total & $32.5 \%$ & $50.0 \%$ & $17.5 \%$ & $100.0 \%$ \\
\hline
\end{tabular}

FIGURE 4 DISTANCE FROM HOME TO WORKPLACE AND JOB STRESS SEGMENT
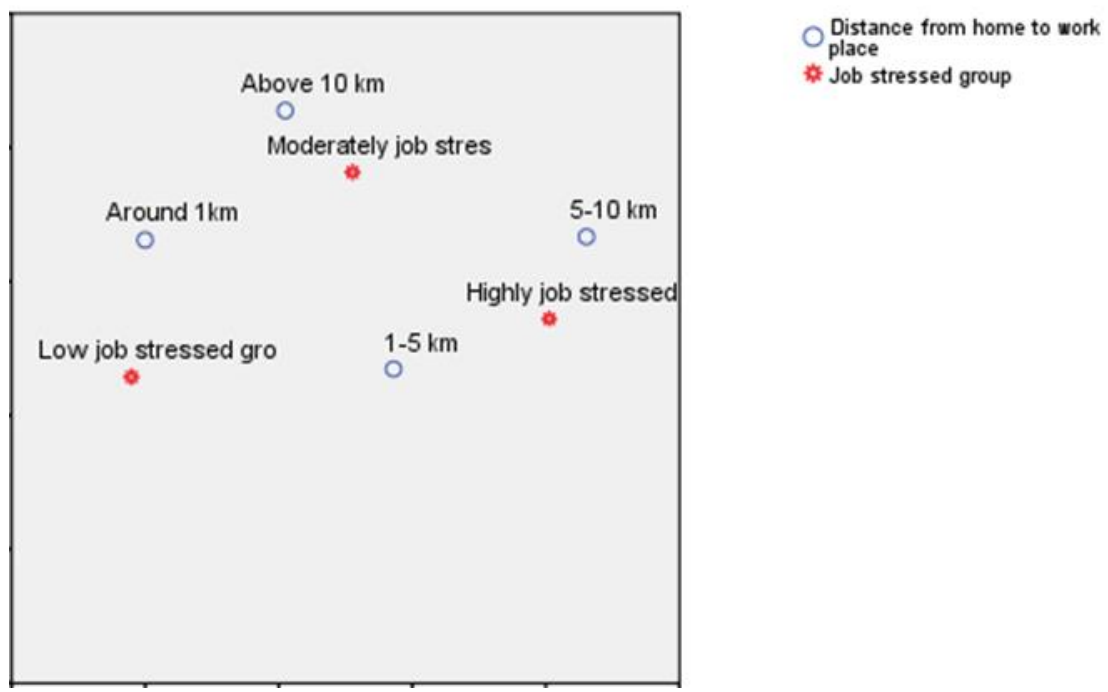

* Job stressed group

It can be inferred from the above cross-tabulation table that the respondents were categorized based on distance from home to workplace and job-stressed group. Those who travel from home to workplace $1-5 \mathrm{~km}$ and 5-10 km come under a highly stressed group. The distance from home to workplace category of around $1 \mathrm{~km}$ comes under a low job stressed group. The distance from home to workplace category of above $10 \mathrm{~km}$ comes under a moderate job stressed group. It shows that those who work close to home fell less stressed than others.

The above figure shows the result of the correspondence analysis clarifying the association between the distance from home to workplace and job stress segment. The figure explicates that those under the category of 1-5 km and 5$10 \mathrm{~km}$ are closely associated with a highly job-stressed group. Those under the category of above $10 \mathrm{~km}$ are closely associated with moderately job stressed group and around $1 \mathrm{~km}$ comes under the low job stressed group.

\section{CONCLUSION}

As our brain and body are constantly interconnected, stress can affect how we feel, think, and act. Among these four factors, job stress ranks highest in the results. Number one on the list is the importance of good interpersonal relationships. Organizational factors make up the second tier. The third factor is environmental, and the final one is a job factors. In the Kurdistan region, hospital staff nurses stressed due to routine shifts and poor organizational structure are mainly influenced by organizational factors that are why it's ranked number one among the four domains. The trouble of work-related pressure isn't new, and a lot of research has previously been performed on this discipline however there are lots of countries wherein this trouble isn't always been given deserving attention. [26-28] Work-related stress is harmful for each employee and organization. This paper highlighted the poor impacts that nurses need to endure due to strain. 
This problem of work-associated strain can quickly be resolved by way of proper action plans and interest from the management. A good area is to pictures is proved to be successful among its competitors. In contrast, the survival of corporations with poor working situations is questionable. There are many studies this is nonetheless wished in this place in nations like Iraq and the Kurdistan Region. Like all other studies, this paper was subject to some limitations. Perhaps, the most difficult obstacles were obtaining information from the very people whom this paper is about (nurses) and their reluctance to provide answers to the questionnaires. Secondly, the privacy policy is like red tape, and hospital staff must not disclose any information without prior permission.

\section{References}

1. Johnson J, Hall LH, Berzins K, Baker J, Melling K, Thompson C. Mental healthcare staff well-being and burnout: A narrative review of trends, causes, implications, and recommendations for future interventions. International journal of mental health nursing. 2018 Feb;27(1):20-32.

2. Hidayat R, Yendra R, Saad M, Rashid M, Anwar K, Afrizal M, Mansur A. Achievement goals, PERMA and life satisfaction: A mediational analysis. Ilkogretim Online. 2020 Mar 1;19(2).

3. Mallett, K., Jurs, S. G., Price, J. H., \& Slenker, S. (1991). Relationships among burnout, death anxiety, and social support in hospice and critical care nurses. Psychological reports, 68(3_suppl), 1347-1359.

4. Madan Mohan G, Prabhu M. A study on students perception about Facebook. International Journal of Contemporary Commerce. 2013;1 (2):64-77.

5. Storoni M. Stress-Proof: The ultimate guide to living a stress-free life. Hachette UK; 2019 Jan 10.

6. Lamaoui M, Jemo M, Datla R, Bekkaoui F. Heat and drought stresses in crops and approaches for their mitigation. Frontiers in chemistry. 2018 Feb 19;6:26.

7. Ingram RE, Luxton DD. Vulnerability-stress models. Development of psychopathology: A vulnerabilitystress perspective. 2005 Jan;46.

8. Xiang Z, Tan S, Kang Q, Zhang B, Zhu L. Longitudinal effects of examination stress on psychological wellbeing and a possible mediating role of self-esteem in Chinese high school students. Journal of Happiness Studies. 2019 Jan;20(1):283-305.

9. Selye H. The stress of life. New York, Mc Gran-Hill Book Company.1956.
10. Finkelstein-Fox L, Park CL, Riley KE. Mindfulness' effects on stress, coping, and mood: A daily diary goodnessof-fit study. Emotion. 2019 Sep;19(6):1002.

11. Lazarus RS, Folkman S. Stress, appraisal, and coping. Springer publishing company; 1984 Mar 15.

12. Hahn VC, Binnewies C, Sonnentag S, Mojza EJ. Learning how to recover from job stress: effects of a recovery training program on recovery, recoveryrelated self-efficacy, and well-being. Journal of occupational health psychology. 2011 Apr;16(2):202.

13. Mark GM, Smith AP. Stress models: A review and suggested new direction.2008; 3, 111-144.

14. Kahu ER, Nelson K. Student engagement in the educational interface: understanding the mechanisms of student success. Higher education research \& development. 2018 Jan 2;37(1):58-71.

15. Burbeck R, Coomber S, Robinson SM, Todd C. Occupational stress in consultants in accident and emergency medicine: a national survey of levels of stress at work. Emergency Medicine Journal. 2002 May $1 ; 19(3): 234-8$.

16. Farrington DP. The development of offending and antisocial behaviour from childhood: Key findings from the Cambridge Study in Delinquent Development. Journal of Child psychology and psychiatry. 1995;6(36):929-64.

17. Anderson R. Stress at work: the current perspective. The journal of the Royal Society for the Promotion of Health. 2003 Jun;123(2):81-7.

18. Hessels J, Rietveld CA, van der Zwan P. Selfemployment and work-related stress: The mediating role of job control and job demand. Journal of Business Venturing. 2017 Mar 1;32(2):178-96.

19. Menzies IE. A case-study in the functioning of social systems as a defence against anxiety: A report on a study of the nursing service of a general hospital. Human relations. 1960 May; 13(2):95-121.

20. Prabhu M, Madan Mohan G. A study on stress among university students in India. International Journal of Business and Administration Research Review. $2014 ; 1(5): 21-33$.

21. Hamid AA, Musa SA. The mediating effects of coping strategies on the relationship between secondary traumatic stress and burnout in professional caregivers 
in the UAE. Journal of mental health. 2017 Jan 2;26(1):28-35.

22. Elsayed S, Hasan AA, Musleh M. Work stress, coping strategies and levels of depression among nurses working in mental health hospital in Port-Said city. International journal of culture and mental health. 2018 Apr 3;1 1 (2):157-70.

23. Simoni PS, Paterson JJ. Hardiness, coping, and burnout in the nursing workplace. Journal of Professional Nursing. 1997 May 1;13(3):178-85.

24. Hevezi JA. Evaluation of a meditation intervention to reduce the effects of stressors associated with compassion fatigue among nurses. Journal of Holistic Nursing. 2016 Dec;34(4):343-50.

25. Hair JF. Multivariate data analysis. 2009.

26. Tyson PD, Pongruengphant R. Five-year follow-up study of stress among nurses in public and private hospitals in Thailand. International journal of nursing studies. 2004 Mar 1:41 (3):247-54.

27. Rasouli N, Abdi M. Comparison of occupational stress level of nurses in public and private hospitals in Qom. Quarterly Journal of Nursing Management. 2019 Mar;8 (2):10-16.

28. Chegini Z. Occupational stress among critical care nurses: A comparative study of public and private sector. Iranian journal of nursing and midwifery research. $2019 \mathrm{Jul} ; 24(4): 306$. 